\title{
Feasibility analysis of collecting environmental protection tax from tourists in an environmental conservation area: a case study of Miyun County
}

\author{
Y. Li ${ }^{1}$, L. Guo ${ }^{2}$, W. Zhu ${ }^{1} \&$ F. Chen ${ }^{1}$ \\ ${ }^{I}$ College of Agriculture and Biotechnology, \\ China Agricultural University, China \\ ${ }^{2}$ Miyun Tourism Administration, China
}

\begin{abstract}
During the last few decades, tourism has undergone rapid growth. However, in some areas, this industry has already destroyed the ecological environment seriously and upset the economic order. As an ecological barrier, an environmental conservation area is not only the support region to ensure the sustainable development of the city, but also the ideal space for citizens to enjoy leisure and recreation. Because of ecological importance, an environmental conservation area should pay more attention to environmental protection and restoration while developing its tourism industry. Collecting environmental tax is a necessity in the environment of a market economy, which is the main economic means to solve environmental problems.

Miyun County is the water source of Beijing, and also an environmental conservation area. The ecological safety of Miyun County concerns the social stabilization of Beijing. By analyzing the impact of tourism and learning from the charge for protecting the environment, this paper suggests that the government of environmental conservation areas should collect environmental protection tax from tourists. Taking Miyun County as an example, the research results showed that tourists who supported the collection of an environmental protection tax while travelling in an environmental conservation area occupy $81.76 \%$ of the investigation number, and the tax rate should be equal to $9.34 \%$ of one-time-expenditure.
\end{abstract}


Based on the different ecological sensitivity of regions, this thesis probes primarily into objections of taxation and the tax rate, and presents a management method for environmental protection tax.

Keywords: feasibility analysis, environmental protection tax, tourism, environmental conservation area.

\section{Introduction}

"Beijing City Master Plan (2004-2020)" readjusted the layout of urban functions. Mentougou District, Pinggu District, Huairou District, Yanqing County and Miyun County are environmental conservation areas of Beijing, the capital of China. The environmental conservation area consists of green ecological shelters intended to ensure the sustainable development of the city. There is an abundance of natural resources and various kinds of plants and animals in the environmental conservation area, which is often a key success factor for tourism. Therefore, these regions are the ideal space for citizens to enjoy leisure and recreation. Because of ecological importance, the environmental conservation area should pay more attention to environmental protection and restoration while developing the tourism industry. Miyun County is not only an environmental conservation area, but also the water source of Beijing. The ecological safety of Miyun County concerns the social stabilization of Beijing. The government should put special emphasis on environmental protection while developing the travel industry, and it is supposed to formulate a policy to settle the conflict between development and environmental protection.

\section{Environmental impacts of tourism}

Tourism is one of the largest and fastest growing industries in the world. With expectations for future growth, the World Tourism Organization predicted that tourism will increase by 50 percent between 1990 and 2010 [1]. While tourism provides considerable economic benefits for many countries, regions and communities, its rapid expansion is also responsible for adverse environmental effects. Natural resource depletion and environmental degradation associated with tourism, for example, are often serious problems in tourism-rich regions [2]. To a larger area, the effect of tourism activity on the environment is flexible, but to a smaller area, tourism may bring about a disastrous impact on the environment and local history. Unregulated tourism can cause some negative effects, such as profit leakage to foreign investors, an increase in local prices, increased crime, pollution, landscape degradation and the depletion of locals' natural resources [3]. Water resources are a prime attraction for tourism and recreational developments. Several studies showed that water has been worst hit by tourism, which not only reduces water quality, but also drains a district of its water resources [3-5].

In this research, taking Miyun County as an example, the Governance Cost Method (GCM) was used to calculate pollution costs of water and waste produced by tourists on the basis of statistics. 


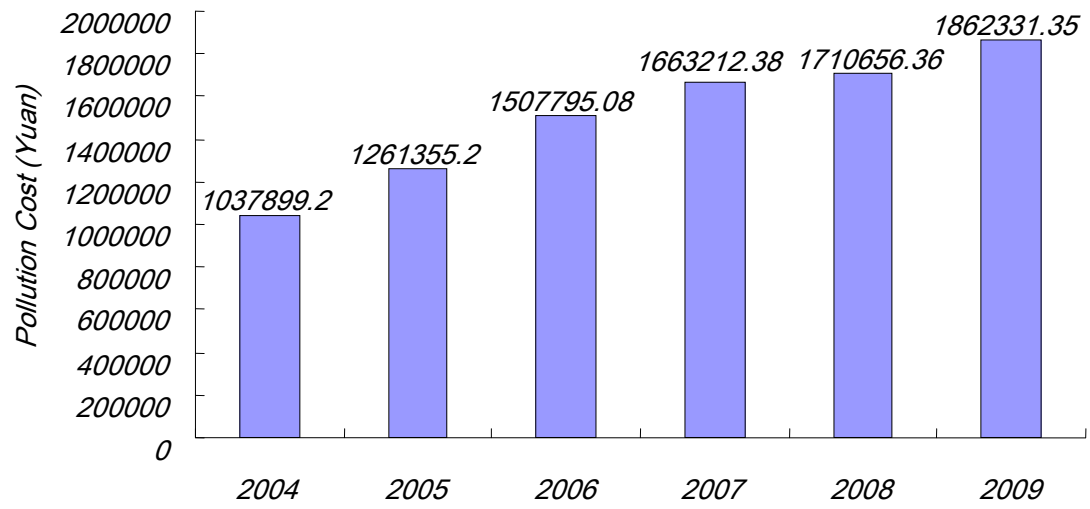

Figure 1: Annual pollution costs of water and waste produced by tourists in Miyun, 2004-2009.

Table 1: Quantity of water and waste from tourists.

\begin{tabular}{|c|c|c|}
\hline & Water (L/ person) & Waste $(1 \mathrm{Kg} /$ person $)$ \\
\hline Hotels \& Inns & 150 & 1 \\
\hline Tourist sites & 6 & 1 \\
\hline Travel agencies & 6 & 1 \\
\hline Leisure Agriculture & 150 & 1 \\
\hline
\end{tabular}

The quantity of water and waste from tourists is listed in Table 1. The water quality in Miyun County conforms to the standards of Grade II. According to the result of the World Bank's study in China, secondary treatment of sewage treatment is 0.77 yuan/t [6]. In the travel industry, the constituents of a tourism activity's waste are similar to household garbage, and in China, the average cost of waste disposal is 125yuan/t [7]. The results showed that pollution costs of water and waste produced by tourists was almost 1,862,331.35 Yuan by 2009 (Figure 1).

\section{Environmental protection tax on tourists}

Environmental protection tax is used as a kind of economic means to regulate pollution and to protect the environment. A number of European countries introduced carbon taxes during the 1990s, although a proposal for an EU-wide carbon-energy tax was ultimately unsuccessful. In the UK, a number of tax 
measures have been implemented primarily with environmental objectives in mind $[8]$.

In the tourism industry, as a kind of new management means, environmental tax arouses the interests of relevant government departments, scholars and experts.

Sultan [9] assessed attitudes of people from Germany, Russia and Turkey towards the bodies responsible for protecting the environment and willingness to pay. The results showed that German tourists were more "environmentally aware" than Russian and Turkish. There were also national differences in tourists' willingness to pay for environmental measures. The results pose important issues for tourism policy in respect of market segmentation and environmental outcomes. Claudio [10] presented and discussed an economic model of taxation in tourism and a case study, both involving a local government and a private developer.

The Government of the Autonomous Community of the Balearic Islands put forward a proposal to introduce a tourist tax on visitors [11]. The Tourism Minister of New Zealand made suggestion to charge international visitors a "green tax", which proposed to be part of a visitor's ticket price [12].

Some scenic spots in China, like Wuyi Mountain, Zhangjiajie and Jiuzhaigou, have begun to collect a resource protection fee, which is usually a charge of $20 \%$ of admission [13]. Unfortunately, the protection fee is not welcomed by some tourists.

\subsection{Research area and method}

The survey was carried out on 5 July to 2 August 2009, which represents the peak season in the area, in Simatai Great wall, Heilongtan, Taoyanxiangu and Purple Paradise. Tourists were asked about their ages, education, whether they had ever paid for environment, whether they wanted to pay environmental protection tax when travelling in an environmental conservation area and their acceptable tax rate.

\subsection{Background characteristics of tourists}

The analysis is based on a sample of 1000 tourists from Miyun County, and the survey secured a $97.6 \%$ response rate. Table 2 shows the background characteristics of tourists.

\subsection{Tourists' environmental protection behaviour}

Tourists were also asked about whether they had ever paid for environment (Table 3). Only 44.98\% of tourists had done. It seems that older tourists were less willing to pay than younger. More than half of tourists aged 20-39 had paid for environment with various methods, while almost $80 \%$ of tourist over the age of $50(78.52 \%)$ never paid for environment.

In our research, 52.94\% of tourists whose households' income amount to 80000-99999 each year chose "Yes". The percentage is significantly higher than other groups. 
Table 2: $\quad$ Background characteristics of tourists.

\begin{tabular}{|c|c|c|c|c|c|}
\hline \multirow{2}{*}{ Age } & $\leq 19$ & $20-29$ & $30-39$ & $40-49$ & $\geq 50$ \\
\cline { 2 - 6 } & 56 & 270 & 330 & 171 & 149 \\
\hline \multirow{2}{*}{ Education } & $\begin{array}{c}\text { Secondary } \\
\text { Academic }\end{array}$ & $\begin{array}{c}\text { High } \\
\text { School }\end{array}$ & $\begin{array}{c}\text { Junior } \\
\text { College }\end{array}$ & Bachelor & $\begin{array}{c}\text { Master } \\
\text { and above }\end{array}$ \\
\cline { 2 - 6 } & 0 & 232 & 238 & 311 & 195 \\
\hline Family & & $40000-$ & $60000-$ & $80000-$ & $\geq 100000$ \\
\hline Income(Yuan) & $\leq 39999$ & 59999 & 79999 & 99999 & 169 \\
\cline { 2 - 6 } & 46 & 210 & 330 & 221 & \\
\hline
\end{tabular}

Table 3: $\quad$ Tourists' environmental protection behaviour.

\begin{tabular}{|c|c|c|c|c|c|c|}
\hline \multirow{3}{*}{ Age } & & $\leq 19$ & $20-29$ & $30-39$ & $40-49$ & $\geq 50$ \\
\hline & Yes & 24 & 152 & 168 & 63 & 32 \\
\hline & No & 32 & 118 & 162 & 108 & 117 \\
\hline \multirow{3}{*}{ Education } & & $\begin{array}{l}\text { Secondary } \\
\text { Academic }\end{array}$ & $\begin{array}{c}\text { High } \\
\text { School }\end{array}$ & $\begin{array}{c}\text { Junior } \\
\text { College }\end{array}$ & Bachelor & $\begin{array}{c}\text { Master } \\
\text { and } \\
\text { above }\end{array}$ \\
\hline & Yes & 0 & 107 & 111 & 135 & 86 \\
\hline & No & 0 & 125 & 127 & 176 & 109 \\
\hline \multirow{3}{*}{$\begin{array}{l}\text { Family } \\
\text { Income } \\
\text { (Yuan) }\end{array}$} & & $\leq 39999$ & $\begin{array}{c}40000- \\
59999 \\
\end{array}$ & $\begin{array}{c}60000- \\
79999 \\
\end{array}$ & $\begin{array}{c}80000- \\
99999 \\
\end{array}$ & $\geq 100000$ \\
\hline & Yes & 14 & 103 & 162 & 117 & 43 \\
\hline & No & 32 & 107 & 168 & 104 & 126 \\
\hline
\end{tabular}

The results showed that differences in 'environmental awareness' did not have a straight relation with differences in educational levels.

\subsection{Tourists' willingness to pay}

Environmental improvements tend to be relatively more beneficial to lowincome groups [14]. Are low-income groups relatively more willing to pay for environmental improvements? $81.76 \%$ of tourists were found to be willing to pay for the maintenance of the environment. Approximately, young, higheducated and high-income tourists were more likely to pay the environmental protection tax during tourism activity than older, low-educated and low-income ones (Table 4).

\subsection{Acceptable tax rate}

Following the approach of earlier studies, tourists were asked if they were willing to pay an extra 2 percent on top of their holiday costs for environmental 
Table 4: Tourists' willing to pay for environment tax.

\begin{tabular}{|c|c|c|c|c|c|c|}
\hline \multirow{3}{*}{ Age } & & $\leq 19$ & $20-29$ & $30-39$ & $40-49$ & $\geq 50$ \\
\hline & Yes & 53 & 203 & 298 & 142 & 92 \\
\hline & No & 3 & 67 & 32 & 29 & 57 \\
\hline \multirow{3}{*}{ Education } & & $\begin{array}{l}\text { Secondary } \\
\text { Academic }\end{array}$ & $\begin{array}{c}\text { High } \\
\text { School }\end{array}$ & $\begin{array}{l}\text { Junior } \\
\text { College }\end{array}$ & Bachelor & $\begin{array}{c}\text { Master } \\
\text { and above }\end{array}$ \\
\hline & Yes & 0 & 177 & 165 & 275 & 181 \\
\hline & No & 0 & 55 & 73 & 36 & 14 \\
\hline \multirow{3}{*}{$\begin{array}{l}\text { Family } \\
\text { Income } \\
\text { (Yuan) }\end{array}$} & & $\leq 39999$ & $\begin{array}{c}40000- \\
59999 \\
\end{array}$ & $\begin{array}{c}60000- \\
79999 \\
\end{array}$ & $\begin{array}{c}80000- \\
99999 \\
\end{array}$ & $\geq 100000$ \\
\hline & Yes & 21 & 163 & 292 & 169 & 153 \\
\hline & No & 25 & 47 & 38 & 52 & 16 \\
\hline
\end{tabular}

Table 5: $\quad$ Tourists' acceptable tax rate.

\begin{tabular}{|c|c|c|c|c|c|}
\hline \multirow{2}{*}{ Age } & $\leq 19$ & $20-29$ & $30-39$ & $40-49$ & $\geq 50$ \\
\cline { 2 - 6 } & $15.58 \%$ & $12.97 \%$ & $8.32 \%$ & $5.08 \%$ & $7.58 \%$ \\
\hline \multirow{2}{*}{ Education } & $\begin{array}{c}\text { Secondary } \\
\text { Academic }\end{array}$ & $\begin{array}{c}\text { High } \\
\text { School }\end{array}$ & $\begin{array}{c}\text { Junior } \\
\text { College }\end{array}$ & Bachelor & $\begin{array}{c}\text { Master } \\
\text { and above }\end{array}$ \\
\cline { 2 - 6 } & & $9.75 \%$ & $9.34 \%$ & $9.43 \%$ & $8.72 \%$ \\
\hline \multirow{2}{*}{ Family } & & $40000-$ & $60000-$ & $80000-$ & \\
& & 59999 & 79999 & 99999 & $\geq 100000$ \\
\cline { 2 - 6 } & $6.67 \%$ & $8.59 \%$ & $8.31 \%$ & $12.08 \%$ & $9.44 \%$ \\
\hline
\end{tabular}

protection. Over $85 \%$ of Turks, almost $80 \%$ of Russians and $70 \%$ of the Germans were willing to pay [9].

In our survey, tourists who were willing to pay environmental protection tax were asked about an acceptable tax rate. The youth and high-income groups seem to be more generous (Table 5). According to the result, the tax rate should be equal to $9.34 \%$ of one-time- expenditure.

\section{Schemes of environmental protection tax}

In Miyun County, any projects, including tourism, that have nothing to do with water supply facilities and protection of water sources, should be forbidden to construct or expand within the first-grade surface sources protection zones. In the other place of environmental protection area, tourism activities should be controlled stringently.

Based on the results of survey and conditions of Miyun County, the paper proposed environmental protection tax schemes and the corresponding implementation strategies as well. 


\subsection{Taxpayer}

All tourists in the environmental conservation area.

\subsection{Tax rate}

The tax rate of environmental protection tax is intended to be $5 \% \sim 15 \%$ of their expenditure in Miyun County. The nearer from the first-grade surface sources protection zone, the higher the tax rate will be. It proposed that the levy could be part of the entrance fee of tourist attractions and other expenditure.

\subsection{Management of environmental protection tax}

Since the good ecological environment can be regarded as a kind of public product, the government can levy environmental protection taxes on beneficiaries, for instance, tourists. The income goes to public budget system for overall arrangement, which should only be used for environmental quality conservation and improvement, including vegetation restoration, conservation of biological diversity and promoting the application of environment-friendly technologies and techniques.

\section{References}

[1] Honey M. Ecotourism and Certification: Setting Standards in Practice. Island Press, Washington, DC.2002.

[2] Frederico Neto. Sustainable Tourism, Environmental Protection and Natural Resource Management: Paradise on Earth? Paper submitted to the International Colloquium on Regional Governance and Sustainable Development in Tourism-driven Economies, Cancun, Mexico, 20-22 February 2002.

[3] Jetmore A. Costa Rica's "Certification for Sustainable Tourism" (CST) Program: A Virtual Success or a Real Failure? Unpublished final paper. Yale University, New Haven, Connecticut, 2004.

[4] Pickering CM, Harrington J, Worboys G. Environmental impacts of tourism on the Australian Alps protected areas - Judgments of protected area managers.Mountain Research \& Development ,3,pp:21-24,2003.

[5] World Tourism Organization (WTO). Concepts and Definitions. 17 May, 2005. http://www.world-tourism.org/step/menu.html.

[6] Wang Shuman, Qu Futian. Water resource accounting and adjustment of GDP - A case study of the developed areas in the eastern part. Journal of Nanjing Agricultural University, 24, pp. 115-11, 2001.

[7] Ding Chun. International Experience of Charge System of Municipal Solid Waste and Enlightenment. Collected essays on finance and economics, 4, pp. 7-13, 2007.

[8] Don Fullerton, Andrew Leicester, Stephen Smith. Environmental Taxes. Working Paper 14197. http://www.nber.org/papers/w14197 
[9] Sultan (Külçür) Baysan. Perceptions of the environmental impacts of tourism: a comparative study of the attitudes of German, Russian and Turkish tourists in Kemer, Antalya. Tourism Geographies 3(2), pp: 218 235, 2001.

[10] Claudio A. G. Piga. Development tax and territorial planning in tourism. http://www.nottingham.ac.uk/ttri/pdf/2003_1.pdf

[11] Teresa Palmer, Antoni Riera. Tourism and environmental taxes. Tourism Management. 6(24), pp: 665-674, 2003.

[12] Tamsyn Parker. Minister floats "green tax" on tourists. 5 June, 2008. http://www.nzherald.co.nz/business/news/article.cfm?c_id=3\&objectid=10 514435\&pnum $=1$

[13] Gong Gaojian. Establish a fair and effective mechanism for ecological compensation. Fujian Daily, 11 September, 2007.

[14] Stina Hökby, Tore Söderqvist. Elasticities of demand and willingness to pay for environmental services in Sweden. The 11th Annual Conference of the European Association. 19 March, 2001 